\title{
Umbilical cord blood banking: from personal donation to international public registries to global bioeconomy
}

This article was published in the following Dove Press journal:

Journal of Blood Medicine

18 June 2014

Number of times this article has been viewed

\section{Carlo Petrini}

Italian National Institute of Health, Rome, Italy
Correspondence: Carlo Petrini Istituto Superiore di Sanità, Via Giano della Bella 34, I-00 I 62 Rome, Italy

Tel +39064990 402I

Fax +390649904303

Email carlo.petrini@iss.it
Abstract: The procedures for collecting voluntarily and freely donated umbilical cord blood (UCB) units and processing them for use in transplants are extremely costly, and the capital flows thus generated form part of an increasingly pervasive global bioeconomy. To place the issue in perspective, this article first examines the different types of UCB biobank, the organization of international registries of public UCB biobanks, the optimal size of national inventories, and the possibility of obtaining commercial products from donated units. The fees generally applied for the acquisition of UCB units for transplantation are then discussed, and some considerations are proposed regarding the social and ethical implications raised by the international network for the importation and exportation of UCB, with a particular emphasis on the globalized bioeconomy of UCB and its commerciality or lack thereof.

Keywords: cord blood banking, economy, ethics, stem cells, transplantation

\section{Context}

The use of umbilical cord blood (UCB) as a source of transplantable hematopoietic stem and progenitor cells was proposed in 1982 by Hal Broxmeyer in a private meeting with Edward A. Boyse and Judith Bard, which led to the foundation of Biocyte Corporation. ${ }^{1}$

UCB stem cells were first successfully used for clinical purposes in 1988, when a team of doctors led by Eliane Gluckman performed a transplant on a 5-year-old suffering from Fanconi's anemia. ${ }^{2}$ Since then, the efficacy of transplants of UCB stem cells for both malignant ${ }^{3,4}$ and nonmalignant ${ }^{5-8}$ diseases has been amply demonstrated: transplants of UCB stem cells can be used to treat acute ${ }^{9,10}$ and chronic ${ }^{11}$ leukemias, lymphomas, ${ }^{12}$ myelodysplastic syndromes, ${ }^{13}$ thalassaemia, ${ }^{14}$ Fanconi anemia, ${ }^{15}$ and other bone marrow failure syndromes, immune deficiencies, ${ }^{16}$ and metabolic/storage diseases. ${ }^{17}$

Since the first transplantation of umbilical cord blood, more than 20,000 UCB transplants have been performed worldwide. ${ }^{18}$

The use of UCB is further boosted by the technique of double UCB transplants. ${ }^{19}$ One of the limits to UCB transplants arises from the fact that only about $10 \%$ of banked UCB units contain enough cells to treat an adult, a problem that can be overcome by combining two units. This approach was proposed by the team led by John Wagner at the University of Minnesota, and the first trial began in 1998. In 2005, the group reported the results achieved in the first 23 recipients treated with double UCB transplants..$^{20,21}$ Since then, other groups have confirmed the efficacy of this technique. ${ }^{22,23}$ 


\section{Storage of UCB: types of biobank}

Storage of UCB is generally recommended for allogeneic use (ie, for a person other than the individual from whom it was collected) for philanthropic purposes, in public banks; for the benefit of the newborn or of a consanguineous child suffering, at the time of collection or previously, from a pathology for which the transplant of UCB stem cells is indicated; or for autologous/directed use in cases of specific pathologies that are as yet undetected, for which there is proven scientific evidence for its potential use, including clinical research.

There are four main types of UCB bank.

\section{Publicly accredited nonprofit UCB banks}

The first public UCB bank was established in 1991 at the New York Blood Center in the United States. ${ }^{24}$ Other banks were soon operating in Paris, France; Milan, Italy; Dusseldorf, Germany, and elsewhere. ${ }^{25}$

UCB is sent to public banks after informed parental consent. Despite numerous differences, the altruistic donation of UCB can be compared with the voluntary, anonymous, and unremunerated donation of blood in transfusion services.

Although there are approximately 22 million bone marrow donors entered in the registries, ${ }^{26}$ for many patients (particularly those of certain racial/ethnic backgrounds), a suitable donor cannot be identified in the required time. Although a matched unrelated bone marrow donor can be found for up to $75 \%$ of patients of Western European origin, for many other ethnic groups, this is not the case, with no more than $20 \%-$ $30 \%$ finding matches. ${ }^{27}$ The probability of finding a human leukocyte antigen (HLA)-matched unrelated donor effectively depends not only on the required degree and resolution of the HLA matching but also on ethnic background. ${ }^{28}$ In some ethnic groups, the incidence of heritable blood-related hemoglobinopathies is particularly high. ${ }^{29}$ There is thus a substantial proportion of patients for whom neither a sibling donor nor an unrelated bone marrow donor can be found, ${ }^{30}$ which was one of the reasons public UCB banks were established. ${ }^{31}$

Public banks are subject to national regulations and may be accredited for participation in international networks. International protocols guarantee quality and uniformity. In 2013, the fifth edition of the NetCord-FACT (Foundation for the Accreditation of Cellular Therapy) international standards was adopted..$^{32}$ Donated UCB units are transferred to the cord blood bank and subjected to a series of controls and tests (minimal cell count, HLA typing, and others) aimed at characterizing the blood and establishing its suitability for storage and therapeutic use. Units of blood that meet the requisites for therapeutic use are submitted to further tests, and the results are recorded in international registries. These units then become available to national and foreign transplant centers throughout the world for allogeneic transplant in patients needing a hematopoietic stem cell transplantation.

Approximately $90 \%$ of the UCB units harvested for storage and subsequent transplantation fail to meet the very strict criteria for clinical use. ${ }^{33}$

Once accepted, the UCB sample becomes the property of the public bank for clinical use (or for research if it is not suitable for transplantation). Donated UCB is always traceable and may therefore be available to the donor should the need arise unless, of course, it has already been released for transplant to another patient. As the possibility of a unit being released over a period of 11 years is about $4 \%$, there is a very high probability that, should a donor need a transplant, his or her own cord blood sample will still be available. ${ }^{34}$

\section{Private autologous UCB banks}

These are commercial facilities that promote the storage of UCB for preventive purposes; that is, in the event the donor or a relative should at some point develop a disease that can be treated by an autologous stem cell transplant (autologous use) or for use where a neonate is diagnosed, either at birth or prenatally, with a pathology that is treatable with an autologous transplant, in which case the UCB is subsequently used by the person from whom it was collected (directed use). Units held in private banks remain the property of the child, under the guardianship of the parents, and are not available to the public. They may, however, be made available to other family members, so that most "private" UCB banks are effectively "private/family" UCBs.

Private banks impose a charge (usually between US $\$ 1,500$ and US $\$ 2,000$ ) on acceptance of the unit, plus an annual storage fee (usually between US $\$ 90$ and US $\$ 200$ ). ${ }^{35}$

At present, the chances of clinical usefulness of autologous stem cells as a means of prevention are very low, and storage in private biobanks for possible future autologous use is not envisaged in the various documents (guidelines, recommendations, position papers, etc) published on the subject by most authoritative institutions. ${ }^{36}$

To date, fewer than ten single case reports have been published of autologous transplants of stem cells using UCB from commercial UCB banks. ${ }^{37-39}$

Numerous studies are available on the probability of autologous use. ${ }^{30,40-42}$ In 2001, Kline estimated this probability at between $1: 20,000$ and 1:200,000, ${ }^{43}$ whereas in 2005, Pasquini et al. estimated the lifetime chance of needing an autologous transplant at 1:400. ${ }^{44}$ The discrepancies in these 
estimates depend on the criteria used (age range, disease spectrum, type of transplant) and range "from a likely overstated 1:10,000 to a more realistic 1:250,000" . ${ }^{45}$ A study by the Italian Associazione Donatori Cellule Staminali noted that the probability that any of the neonates whose umbilical cord blood is stored in private banks for autologous use may one day need a transplant of hematopoietic stem cells is effectively between 1:75,000 and 1:100,000, or between $0.0013 \%$ and $0.0010 \% .{ }^{46}$ Most specialists are skeptical regarding purely private UCB banks, which are seen as making a profit by offering illusory promises of decidedly improbable benefits for the child whose UCB is stored. ${ }^{47}$ Private storage can even be seen as damaging the public interest, as it removes from the international networks resources that could otherwise be of therapeutic benefit to persons other than the donor. ${ }^{48}$

It should be remembered, however, that numerous clinical trials involving a variety of diseases are underway. This means that the scientific picture is in continual flux and that attitudes toward autologous storage may evolve quickly. As Webb observed, if further research endorses the efficacy of UCB in the treatment of cerebral palsy or in other areas of regenerative medicine, the stance of the scientific community regarding private UCB banks could change: they might become a useful complement to public biobanks, which are often hampered by financial straits and, at times, by excessively tight regulatory constraints. ${ }^{49}$

In an opinion issued March 15, 2011, the Comité ItaloFrançais pour le bon usage du sang du cordon ombilical (Italo-French Commission for the Proper Use of Umbilical Cord Blood) stated that the collection and storage of UCB from healthy newborns for "preventive" purposes, for possible future autologous use, as practiced by private organizations on a fee-paying commercial basis, is in contrast to "the general public interest and, in particular, the interests of patients with oncohaematological, genetic haematological, immunological or dysmetabolic diseases that can be cured in the majority of cases with allogeneic transplants of haematopoietic stem cells and not with autologous cells, and who thus need a vast pool of altruistic donations from which to draw HLA-matched donors". ${ }^{50}$ In its Position Statement on Cord Blood for Autologous Use, NetCord states: "Since the therapeutic benefit of allogeneic cord blood transplantation has been convincingly demonstrated, NetCord primarily promotes banking for allogeneic stem cell transplantation. Banking for autologous purposes may be considered if such storage is part of a program whose primary mission is the use of cord blood units for allogeneic stem cell transplantation." ${ }^{51}$
Notwithstanding this, private biobanks are expanding rapidly both in size (ViaCord, which in 2000 stored only a few thousand UCB units, held over 300,000 units in 2013) and in number. It is estimated that in 2011, approximately 1 million UCB units were stored in more than 130 private UCB banks worldwide. ${ }^{52}$ Private biobanks are present in numerous countries, with the exception of some countries, such as Italy, ${ }^{53}$ where they are banned. ${ }^{54}$ However, banks based in countries in which they are allowed often operate local agencies in countries where they are not, offering to export and store units abroad on a fee-paying basis. The high number of units stored in private banks is also linked to the fact that these facilities apply less stringent criteria for acceptability (particularly regarding the number of cells and their viability, clonogenic capacity, and sometimes, sterility) than do public banks, which are regulated by international quality standards. There is consequently a risk that units stored in private banks may be of low quality or low yield. ${ }^{55}$ The fact that private UCB banks do not generally invest in research and are inevitably in competition among themselves is a further cause for concern.

There are, nonetheless, many reasons why parents still choose to pay for private storage.$^{48}$ Rosenthal et al and Smith identify three reasons in particular: a tendency for many parents to consider it a form of insurance against future illness; the fact that some parents may choose to store UCB cells in response to natural parental anxiety and concerns regarding their children's health, plus their innate desire to offer them whatever protection is available; and finally, some parents may be seeking some sense of control in a setting in which control is often hard to find. ${ }^{45,48}$

\section{Related family UCB banks (by kinship)}

"Directed" storage can be an important resource for newborns or family members suffering from pathologies for which treatment with UCB stem cells is scientifically proven and clinically appropriate. ${ }^{30}$ This approach is clinically indicated and validated, in particular, in families where the mother is pregnant and has an existing child, or a known risk of having a child, affected with a disease that can be treated through transplantation of allogeneic HLA-compatible hematopoietic stem cells. ${ }^{56}$

Although in the case of public UCB banks all healthy neonates are potential donors, family-directed banking implies a more focused approach to identifying the few candidates to benefit from cord blood collection. ${ }^{57}$

Although the total number of directed UCB units stored is unknown, it is small in comparison with those in either 
allogeneic public banks or autologous private banks. ${ }^{30} \mathrm{Few}$ countries have a centralized program for family-directed UCB harvesting and storage. Private UCB banking for family use is mainly a spin-off from autologous banking. Occasionally a sibling may benefit from this form of banking.

In countries in which direct banking programs do exist, it is usual to establish official lists of recognized indications for which the transplantation of hematopoietic stem cells has been proven to be effective and for which the harvesting of directed UCB is appropriate.

In Italy, for instance, the Ministry of Labor, Health and Social Policies issued a list, which was drawn up by the Gruppo Italiano per il Trapianto di Midollo Osseo, Cellule Staminali Emopoietiche e Terapia Cellulare (Italian Group for the Transplantation of Bone Marrow, Haematopoietic Stem Cells and Cell Therapy) and annexed to the ministerial decree of November 18, 2009. ${ }^{53}$

Family-directed UCB transplantation has several advantages over unrelated UCB transplantations, including greater likelihood of survival, decreased graft-versus-host disease, and the opportunity to recollect bone marrow cells from the same donor in the event of relapse or rejection. ${ }^{56}$

It is therefore to be hoped that the numbers of familydirected UCB banks will increase. ${ }^{9}$

\section{Hybrid private-public UCB banks}

Other types of blood banks also exist, ${ }^{52}$ for example, hybrid private-public facilities, although they are not numerous. Some of these banks divide the UCB into two parts, one of which is stored privately for autologous or related use and the other of which is donated to the public network. The challenge facing these banks is to combine the known potential of public-sector allogeneic storage with the possible, albeit currently remote, applications of autologous storage in specific fields of regenerative medicine. It is hoped that in the future, treatments may be found for tissues or organs damaged by degenerative diseases. One of the more interesting possibilities being studied ${ }^{58}$ is the use of UCB stem cells for functional neuroregeneration in children with cerebral palsy. ${ }^{59,60}$

One hybrid private-public facility is Virgin Bank, established by Richard Branson. ${ }^{61}$ The system adopted envisages the storage for autologous use for regenerative medicine of $20 \%$ of the blood sample, with the remaining $80 \%$ being passed to the public network of registries. This scheme has aroused interest in several quarters. ${ }^{62}$

Another example of a hybrid model is StemCyte, which offers both private and public UCB storage. The former holds units for private use (family-directed), whereas units held in the latter are available to the general public.

Some private banks store UCB for autologous use while simultaneously creating links with networks managed by universities and public institutions. In some nations (eg, Spain), public banks will store UCB for autologous use, but on the condition that it is made available if requested for a patient unrelated to the donor's family. ${ }^{63,64}$ Another model of hybrid UCB bank allows parents to donate UCB to public banks while retaining ownership rights for a specified period sufficient to cover the eventual needs of the child. ${ }^{49}$

The attitude to hybrid UCB banks is one of caution: "Discussion about the development of hybrid [cord blood banks] models that could combine efforts to support all banking activities is the subject of intense controversy because of ethical, scientific, regulatory, economic and social concerns." ${ }^{56}$

The World Marrow Donor Association has published a paper on the subject. The association recommends that "where the operator of a public bank also has a private banking operation or where it affiliates with a private bank ....:

1. Banked Cells intended for public use must meet all regulatory and accreditation standards ....

2. Banked Cells collected solely for private use should not be stored with Banked Cells that may enter the public inventory unless they meet all regulatory and accreditation standards at the time of processing and storage.

3. Joint marketing must clearly identify the current scientific understanding of the use of the Banked Cells in both public and private use ....

4. Any claims of accreditation should clearly identify to which parts of the operation the accreditation applies ....

5. Informed consent should fully disclose the timing and circumstances upon which the Banked Cells would convert to public use.

6. Banked Cells listed for public use should be fully consented for public use and not be subject to further consent from the donating family once they are placed in the public inventory ....

7. Banked Cells not consented for eventual public use at the time of collection should never be placed into the public inventory." ${ }^{\prime \prime 5}$

Some form of public-private partnership could bring financial support to the public biobank network, which is frequently underfunded, but the difficulty lies in identifying a suitable model. ${ }^{66}$ 


\section{International registries and networks}

Accredited public UCB banks are linked to national registries. In the United States, for example, the federal government enacted legislation in 2005 to support the National Cord Blood Inventory, which is a registry of publicly available UCB units. ${ }^{67}$

National registries are linked, in turn, to international registries, which permit identification of the most suitable sample for each patient requiring a transplant.

The international standards with which all biobanks linked to the registries must comply are necessary to guarantee not only that products meet international best-practice standards but also the efficiency of the administrative procedures needed to organize the registries and source UCB units for transplantation.

The search for UCB units is usually set in motion by either a hematologist or an oncologist through referral to a transplant center. The search usually initiates in a domestic registry network before being extended to international networks, as the acquisition of UCB units from a foreign country inevitably implies increased costs.

UCB registries thus function as a hub linking donors, recipients, clinics, biobanks, and regulatory agencies.

The size of each registry is naturally of crucial importance: the larger the number of units registered, the greater the probability of finding a clinically useful match between donor and recipient.

The leading international registries are listed in Table 1.

\section{Optimal size of UCB banks}

Various studies have estimated the number of banked UCB units required to meet the needs of a given population. To decide how many UCB units should be included in an inventory, the benefits in terms of the greater numbers of transplants and life-years gained must be weighed against the costs involved. Identifying the appropriate size of national inventories is thus crucial not only for clinical reasons (to ensure a match between supply and demand) but also for reasons of economic sustainability.

In 2005, the Committee on Establishing a National Cord Blood Stem Cell Bank Program commissioned an extensive study, ${ }^{68}$ and more recently, Querol et al used a sophisticated method to show that high probabilities of good HLA matches (5/6) can be achieved with an inventory of around 1 or 2 units per 1,000 population. The authors analyzed the characteristics necessary to define the optimal size of a national UCB bank for the United Kingdom, estimating that the development of a national inventory of 50,000 units
Table I Main international networks and registries

\section{Registries}

Bone Marrow Donor Worldwide (https://www.bmdw.org)

- One of the first and largest such organizations, founded in Leiden in 1988.

- A voluntary cooperative organization designed to provide a centralized database of bone marrow donors and available UCB units.

- In January 2014, the organization included 72 stem cell donor registries from 52 countries, and 48 UCB banks from 33 countries, for a total of more than 600,000 registered UCB units.

Center for International Blood and Marrow Transplant Research (http:// www.cibmtr.org)

- Includes the National Bone Marrow Donor Program, the Autologous Blood and Marrow Transplant Registry, and the former International Bone Marrow Registry.

- Collects data on recipients of allogeneic blood and bone marrow transplants worldwide and on autologous blood and bone marrow transplants performed in North and South America.

NetCord Foundation (http://www.netcord.org)

- Nonprofit organization founded in 1998.

- Promotes studies and research on the collection, processing, characterization, preservation, and ex vivo expansion of placental blood for clinical cellular therapy on an international level.

- In January 2014, the foundation comprised 21 member, three associate member, eleven provisional member, and three corporate member UCB banks from 21 countries.

- UCB banks participating in NetCord account for more than half the UCB preserved in public facilities worldwide.

- The foundation cooperates with the Foundation for the Accreditation of Cellular Therapy (FACT) to formulate international standards. EUROCORD (http://www.eurocord.org)

- Nonprofit organization established in 1996 by the European Group for Blood and Marrow Transplantation.

- Promotes research, training, information, standardization, quality control, and accreditation of facilities in the field of hematopoietic stem cell transplantation.

Abbreviation: UCB, umbilical cord blood.

with a cell dose threshold of 1,250 million nucleated cells per UCB unit would yield a $59 \%-83 \%$ probability of finding at least one unit (median number, nine units) within the 5/6 HLA match category for patients with a body weight of $50 \mathrm{~kg}$. An inventory of 50,000 units in the United Kingdom would cost $£ 68$ million. The authors concluded that a bank containing 50,000 units would be optimal for the United Kingdom and that larger banks would only marginally increase the chance of finding suitable units. ${ }^{69}$ Inventories of 50,000-100,000 units would thus be suitable for European countries with larger populations. ${ }^{70}$

\section{UCB as a source of blood- derived products}

Donated UCB units can also be used to obtain products that are (at least potentially) marketable. Units that are unsuitable for storage and transplantation can, in fact, potentially be used 
for research purposes ${ }^{71}$ or for the preparation of blood-derived products, particularly platelet gel, ${ }^{72}$ subject to the consent of the parents who donated the sample. This aspect is not without significance if we consider that more than $90 \%$ of donated cord blood units are unsuitable for preservation for purposes of transplantation (eg, because they contain too few cells) or become unsuitable at some time (eg, through deterioration). The chance to prevent this biological resource being wasted can thus be transformed into an opportunity to increase the value of the altruistic gesture of donation, ${ }^{73}$ or even a source of gain.

Platelet gel is a blood-derived product obtained by aggregating concentrated platelets with calcium and biological or pharmacological proaggregation factors and is applied topically. Thanks to its plasticity and ease of modeling at the site of application, this preparation promotes and accelerates the repair of both cutaneous and bone tissues. It is used in maxillofacial surgery, orthopedics, and the treatment of torpid cutaneous ulcers. On account of its reparative properties, the potential uses of platelet gel have expanded steadily into different fields, including aesthetic surgery and medicine. ${ }^{74}$

Because UCB is donated for philanthropic purposes, the exploitation for profit of platelet gel or other products derived from UCB could raise concerns. This problem could be avoided if these blood-derived products were used within the same health care facilities in which the units were harvested and did not enter any kind of commercial network.

It would naturally be necessary to include appropriate information on the relevant informed consent forms and to give parents the option both to refuse consent to the use of cord blood for the preparation of blood-derived products and to place restrictions on its use, such as limiting the use of platelet gel for therapeutic, but not cosmetic, purposes.

\section{Costs and sustainability of public UCB biobanks}

The costs for each unit of UCB released from international networks for transplantation purposes have been estimated by various authors. The calculations used different settings and parameters (eg, inventory size, numbers of biobanks, duration of storage, percentages of release, etc) and considered the expenses incurred in the various phases (eg, labor costs, reagents and diagnostics, disposables, depreciation and maintenance, laboratory tests, overheads).

One of the earliest of these studies was published by Sirchia et $\mathrm{al}^{75}$ and estimated the fees per UCB unit released for transplantation that would allow cost recovery after 10 years. The authors considered three possible models with varying numbers of UCB banks and inventory sizes and took five UCB units per 1 million population per year as the rate of use for transplantation. This equates to an annual requirement of 280 units for Italy (which is approximately four times the actual figure normally reported). The figures they obtained were $\$ 15,061, \$ 12,666$, and $\$ 11,602$, respectively, for inventories of $1,500,5,000$, and 10,000 units. $^{75}$

A more recent study by Howard et al estimated that the fee per released unit varies between $\$ 15,336$ (for an inventory of 50,000 UCB units) and $\$ 92,675$ (for an inventory of $300,000$ units $).{ }^{68}$

A third economic study is to be found in the Spanish Plan Nacional de Sangre de Cordón Umbilical. ${ }^{76}$ This study concluded that the minimum cost for each UCB unit is $€ 1,300(\$ 1,760)$ for collection and processing and $€ 40 /$ year (\$65/year) for storage. These costs are based on a $50 \%$ discard rate, although in fact the figure is usually higher, with consequently higher costs. A discard rate of $65 \%$ raises the cost to $€ 1,600(\$ 2,170)$, and when the discard rate rises to $80 \%$, the cost rises to $€ 1,900(\$ 2,580)$. The cost for an inventory of 50,000 units with a discard rate of $50 \%$ thus amounts to about $€ 65$ million ( $\$ 84$ million). In the latter case, assuming the release of about 200 units/year, the cost of each unit is around $€ 20,000$. $^{76}$

A more detailed study was performed by Bart, who compared unrelated donor UCB and adult stem cell procurement. ${ }^{34}$ The two processes are, of course, different (UCB units are harvested and cryopreserved at the time of collection, whereas adult donors are recruited for HLA typing only). Bart considered the procurement fees of the leading registries (Bone Marrow Donors Worldwide, World Marrow Donor Association, and Swiss Foundation Blood Stem Cells) for 2009 and calculated an average figure for each world region. The result was a cost of $\$ 34,200$ in the Americas, $\$ 24,300$ in Europe, and \$20,600 in the Asia-Pacific region. Considering that in 2009 the numbers of UCB units used was 1,702 in the Americas, 815 in Europe, and 1,232 in the AsiaPacific region, the total expenses for the three zones were, respectively, \$58,208,400, \$19,804,500, and \$25,379,200. Bart then compared the costs for the three main sources of hematopoietic stem cells (UCB, bone marrow, and peripheral blood stem cells), using the estimates of Sirchia et al ${ }^{75}$ and Howard et $\mathrm{al}^{68}$ for UCB and those of Kollman et $\mathrm{al}^{77}$ for bone marrow (Kollman et al used data from the US National Marrow Donor Program and calculated total costs for the recruitment of a new donor of between $\$ 115$ for white persons and \$141 for non-Caucasians). Bart applied these authors' models to various scenarios (eg, inventories of different 
sizes and "returns of inventory") to obtain an overall picture of worldwide costs for "stem cell products" and compared UCB, bone marrow, and peripheral blood stem cells. To do this, he multiplied the available products (UCB units banked and registered adult donors) by the average costs per product, together with the costs of provided products (provided UCB versus bone marrow or peripheral blood stem cells) multiplied by the cumulative total number.

The "price per product" (PPP) was calculated by dividing the total cost by the number of products delivered. Bart called this a "system-based" approach (ie, the costs were all incurred by a single health system) and then considered an "institution-based" scenario in which the costs for delivered products were regarded as profits and subtracted from the total cost of building up an inventory. For the period 1999-2009 (or 1997-2009 in the case of adult stem cells), Bart estimated, for the "health system" approach, both total costs for cord blood of between $\$ 6.8$ and $\$ 25.5$ billion (during the period 1999-2009), which, when divided per product provided, give unit costs of $\$ 318,890$ and $\$ 1.19$ million per product, and total costs for adult stem cell donation of between $\$ 4.2$ and $\$ 5.8$ billion, which, divided by cumulative donations, give a unit price of between $\$ 47,638$ and $\$ 65,681$ per product provided (for bone marrow and peripheral blood stem cells, respectively). When an "institution-based" approach, which is more realistic than the "health-system" approach, is applied, the price differential between cord blood and adult stem cell products falls approximately within the same range. The data elaborated by Bart indicate a considerable difference between the costs for UCB and adult stem cells (from bone marrow or peripheral blood), which is, among other factors, because the vast majority of stored UCB units are never used for transplants.

Taken together, these studies reveal the variability in fees that biobanks receive for the release of blood units to transplant centers. At this time, the fee is approximately $\$ 25,000$. However, these costs can rise considerably; in the United States, for instance, the figure is generally around $\$ 40,000 .{ }^{49}$

The costs rise further if we consider that in a growing number of cases, patients receive multiple transplants to increase the likelihood of therapeutic success. ${ }^{78}$

The whole issue of costs should nonetheless be considered in a broad perspective: It should not be forgotten that engraftment with UCB takes longer (21-35 days) than engraftment with cells taken from an adult donor (20 days), thereby implying possibly higher hospitalization costs. ${ }^{49}$ The total expense should also consider the overall long-term survival of the patient and the possibility that a patient treated with a less-expensive procedure may relapse more quickly.

All of these considerations apply in the public system, which is often subsidized. In the United States, for instance, public UCB banking is financed through a combination of government grants, private donations, and the fees received for UCB units released for transplant purposes. The present US financing system was established in the Stem Cell Therapeutic and Research Act of 2005 and renewed in 2010, and in 2005, the US Congress granted $\$ 79$ million "to assist in the collection and maintenance of 150,000 new units of highquality cord blood to be made available for transplantation". ${ }^{79}$ In Switzerland, the Swiss Foundation Blood Stem Cells implemented a program to expand the UCB inventory from 1,000 to 4,000 units. The cost (between Swiss franc 500,000 and Swiss franc 900,000 , or $\$ 554,000$ and $\$ 997,000$, per year) was borne by the foundation. ${ }^{34}$

The challenge is to reduce the costs of the whole process of UCB banking (harvesting, processing, storage) without compromising quality and safety levels. Unfortunately, this is an extremely difficult goal to achieve.

Although this article is concerned with the bioeconomic aspects of public UCB banking, it is worthwhile mentioning a few data regarding the costs involved in private UCB banking, where profit is the stated objective. According to BCC Research in Wellesley, Massachusetts, private UCB banks earned $\$ 4.5$ billion worldwide in $2010 .{ }^{49}$

Kaimal et al used "decision analysis" to study the costs involved in private UCB banking. This method tracks hypothetical groups of people and permits a comparison of the expected costs and health benefits of two strategies (private UCB banking and no banking). Assuming a cost of $\$ 3,620$ for UCB banking storage over the course of 20 years, a $0.04 \%$ chance of requiring an autologous stem cell transplant, a $0.07 \%$ chance of a sibling requiring an allogeneic stem cell transplant, and a $50 \%$ reduction in the risk of graft-versus-host disease if a sibling uses banked UCB stem cells, private banking costs an additional $\$ 1,374,246$ for each life-year gained. The authors conclude that private UCB banking is not generally cost-effective, except for families with a child who has a very high probability of needing a stem cell transplant. ${ }^{80}$

\section{From donation to global bioeconomy A globalized bioeconomic network}

Although many UCB registries originated at local level, where "local" may cover an entire nation, they are now at 
the center of a network linking donors, clinicians, banks, regulatory agencies, and recipients. Size is a crucial factor for registries: The larger they are, and the more heterogeneous their inventories, the greater the probability of finding a clinically useful match between donor and recipient.

The global network within which UCB and capital move can be considered an example of "tissue economy" 81 made possible by vast infrastructures and complex organizational systems. The movement of blood units can be included in what Esposito called a nascent "immunitary paradigm", in which politics, biology, and the economy are ever more closely interwoven. ${ }^{82,83}$ According to Brown et al, the emergence of the UCB banking sector has come about in parallel with the process of globalization and with previously unknown levels of ethnic migration and the heterogenization of populations that were formerly more homogeneous and foreshadows the "economisation of life in the international cord blood market" ${ }^{84}$ In other words, registries may contribute to the creation of a multidimensional "immunitary community" that is not only clinical but also economic.

Esposito points out that immunitas and communitas have a common etymological root in munus, the literal meaning of which is "gift" or "obligation". Communitas expresses a relationship and a link of reciprocity, whereas immunitas denotes a resistance to reciprocity, a defense and a protection against what is external. In legal and medical usage, "immunity" is a form of exemption or untouchability denoting defense and protection that is, thus, in contrast to an exchange or relationship. Esposito nevertheless suggests that although immunitas is a "power to preserve life" directed toward defending it, it can also lead to new forms of circulation, ${ }^{83}$ of which the transplantation of cells, organs, and tissues is an example.

However, this global movement is not uniformly distributed, and discrete "bioeconomic regions" can be discerned. ${ }^{85}$ One of the key reasons for this unevenness is undoubtedly organizational, as seen in regional differences in the organization of the childbirth centers in which blood is harvested, the biobanks in which it is stored, and the networks of biobanks that make it available. Another reason, in some regions, is associated with the presence of ethnic minorities. Most UCB banks were initially established to address the problem of a disproportionately high percentage of Caucasian populations in bone marrow registries. ${ }^{24}$ Increasing migration, meanwhile, is leading to a gradual redistribution of genetic characteristics, and the heterogeneity of populations calls for greater access to UCB units that can be used worldwide. Several nations have included provisions to encourage the harvesting of UCB from key minorities in their cord blood collection procedures. The international dimension is decisive, among other things, in contributing to the biovalue of UCB because of the need for access to widely dispersed immunotypes.

A few figures on the release, destination, and use of UCB allows a comparison between imports and exports and reveals the irregularity in movements. In some nations, exports clearly outnumber imports. In Australia, Belgium, and Germany, for example, more than $80 \%$ of the total units traded are exported, and in other nations, such as France and the United States, approximately $70 \%$ of traded units are imported. ${ }^{86}$ Whether a nation is self-sufficient or needs to import units reflects not only the level of local organization but also on the homogeneity of its population. Many Southeast Asian countries, for example, are self-sufficient, probably because of the relative homogeneity of their populations. Nor are strong exporting countries necessarily self-sufficient. In the United Kingdom, for instance, exports outnumber imports, but import costs are higher. It is estimated that the United Kingdom has the second highest percentage of rare immunities (41\%) across global registries. ${ }^{87}$

This lack of homogeneity may tarnish the model of "community" described earlier: "The international trade in cord blood is not necessarily a freely given expression of common community." Instead, it represents a form of protection through which the trade's participants protect themselves from the vulnerability generated by their dependence on the importation of premium goods. ${ }^{84}$ These inconsistencies are being addressed through improvements in organization.

\section{The thin line between unremunerated donations and trade}

The fees charged for the release of UCB units for transplantation frequently exceed the actual outlay incurred by biobanks for storage and preservation. The international dimension contributes to the economic value of $\mathrm{UCB}$, as it enables biobanks to include indirect costs beyond those incurred in harvesting and storage in the charges applied when cord blood is released in the global marketplace. This is justified on the basis that these services should be able to offset their costs and receive some compensation for the economic risks and the financial burden incurred in the process of collecting and storing blood samples. ${ }^{85}$

Although the system is based on donations and altruism, the transactions described here could be seen as a form of masked commerce. This would violate the principle of noncommerciality of the human body or its parts that is enshrined in several respected documents such as the World Health 
Organization's “Guiding Principles on Human Cell, Tissue and Organ Transplantation" (resolution WHA 63.22), which states: "Cells, tissues and organs should only be donated freely, without any monetary payment or other reward of monetary value. Purchasing, or offering to purchase, cells, tissues or organs for transplantation, or their sale by living persons or by the next of kin for deceased persons, should be banned." 88 Under the heading "Prohibition of financial gain", Article 21 of the Convention for the Protection of Human Rights and Dignity of the Human Being with Regard to the Application of Biology and Medicine: Convention on Human Rights and Biomedicine similarly states that, "The human body and its parts shall not, as such, give rise to financial gain." " ${ }^{\circ 9}$ In addition, Article 3.2 of the Charter of Fundamental Rights of the European Union likewise affirms "the prohibition on making the human body and its parts as such a source of financial gain". ${ }^{90}$

This does not, however, prevent the existence in several states that are signatories to these and other documents prohibiting trade of the human body or its parts, not only of regulations that allow the sale and purchase of cells and tissues, but also of official tariffs for such transactions. Public-sector hospitals in these states may legally sell biological samples to industrial concerns. ${ }^{91}$

These considerations are not intended to call into question the foundation of a system based on the voluntary, unremunerated donation of UCB (namely, a gesture of altruism), but it must be recognized that even in systems founded on unpaid and voluntary donations, the transfer of cells, tissues, blood, and organs from one country or continent to another generates the movement of not inconsiderable sums of money; as a consequence, there is an inevitable "impact of commercialization" in this field. ${ }^{92}$

\section{Disclosure}

The author reports no conflicts of interest in this work.

\section{References}

1. Ballen KK, Gluckman E, Broxmeyer HE. Umbilical cord blood transplantation: the first 25 years and beyond. Blood. 2013;122(4): 491-498.

2. Gluckman E, Broxmeyer HA, Auerbach AD, et al. Hematopoietic reconstitution in a patient with Fanconi's anemia by means of umbilical-cord blood from an HLA-identical sibling. $N$ Engl J Med. 1989;321(17): 1174-1178.

3. Brunstein CG, Weisdorf DJ. Future of cord blood for oncology uses. Bone Marrow Transplant. 2009;44(10):699-707.

4. Rocha V, Kabbara N, Ionescu I, Ruggeri A, Purtill D, Gluckman E. Pediatric related and unrelated cord blood transplantation for malignant diseases. Bone Marrow Transplant. 2009;44(10):653-659.

5. Rocha V, Gluckman E; Eurocord and European Blood and Marrow Transplant Group. Clinical use of umbilical cord blood hematopoietic stem cells. Biol Blood Marrow Transplant. 2006;12(1 Suppl 1):34-41.
6. Kögler G, Critser P, Trapp T, Yoder M. Future of cord blood for non-oncology uses. Bone Marrow Transplant. 2009;44(10):683-697.

7. Prasad VK, Kurtzberg J. Umbilical cord blood transplantation for nonmalignant diseases. Bone Marrow Transplant. 2009;44(10):643-651.

8. Horowitz ME, Chao N. Umbilical cord blood transplantation for treatment of nonmalignant disorders. In: Broxmeyer HE, editor. Cord Blood: Biology, Transplantation, Banking, and Regulation. Bethesda, MD: AABB Press; 2011:477-486.

9. Rocha V, Cornish J, Sievers EL, et al. Comparison of outcomes of unrelated bone marrow and umbilical cord blood transplants in children with acute leukemia. Blood. 2001;97(10):2962-2971.

10. Eapen M. Cord blood transplantation for leukemia in children. In: Broxmeyer HE, editor. Cord Blood: Biology, Transplantation, Banking, and Regulation. Bethesda, MD: AABB Press; 2011:467-476.

11. Laughlin MJ, Eapen M, Rubinstein P, et al. Outcomes after transplantation of cord blood or bone marrow from unrelated donors in adults with leukemia. N Engl J Med. 2004;351(22):2265-2275.

12. Majhail NS, Weisdorf DJ, Wagner JE, Defor TE, Brunstein CG, Burns LJ. Comparable results of umbilical cord blood and HLA-matched sibling donor hematopoietic stem cell transplantation after reducedintensity preparative regimen for advanced Hodgkin lymphoma. Blood. 2006;107(9):3804-3807.

13. Woodard P, Carpenter PA, Davies SM, et al. Unrelated donor bone marrow transplantation for myelodysplastic syndrome in children. Biol Blood Marrow Transplant. 2011;17(5):723-728.

14. Ruggeri A, Eapen M, Scaravadou A, et al; Eurocord Registry; Center for International Blood and Marrow Transplant Research; New York Blood Center. Umbilical cord blood transplantation for children with thalassemia and sickle cell disease. Biol Blood Marrow Transplant. 2011;17(9):1375-1382.

15. Gluckman E, Rocha V, Ionescu I, et al; Eurocord-Netcord and EBMT. Results of unrelated cord blood transplant in fanconi anemia patients: risk factor analysis for engraftment and survival. Biol Blood Marrow Transplant. 2007;13(9):1073-1082.

16. Tsuji Y, Imai K, Kajiwara M, et al. Hematopoietic stem cell transplantation for 30 patients with primary immunodeficiency diseases: 20 years experience of a single team. Bone Marrow Transplant. 2006;37(5): 469-477.

17. Gratwohl A, Baldomero H. European survey on clinical use of cord blood for hematopoietic and non-hematopoietic indications. Transfus Apher Sci. 2010;42(3):265-275.

18. Gluckman E, Ruggeri A, Rocha V, et al; Eurocord, Netcord, World Marrow Donor Association and National Marrow Donor Program. Family-directed umbilical cord blood banking. Haematologica. 2011;96(11):1700-1707.

19. Brunstein CG, Wagner JE. Double umbilical cord transplantation for malignant disorders. In: Broxmeyer HE, editor. Cord Blood: Biology, Transplantation, Banking, and Regulation. Bethesda, MD: AABB Press; 2011:503-528.

20. Barker JN, Weisdorf DJ, DeFor TE, et al. Transplantation of 2 partially HLA-matched umbilical cord blood units to enhance engraftment in adults with hematologic malignancy. Blood. 2005;105(3): 1343-1347.

21. Wagner JE. Should double cord blood transplants be the preferred choice when a sibling donor is unavailable? Best Pract Res Clin Haematol. 2009;22(4):551-555.

22. Kang HJ, Lee JW, Kim H, Shin HY, Ahn HS. Successful first-line treatment with double umbilical cord blood transplantation in severe aplastic anemia. Bone Marrow Transplant. 2010;45(5):955-956.

23. Stanevsky A, Shimoni A, Yerushalmi R, Nagler A. Double umbilical cord blood transplant: more than a cell dose? Leuk Lymphoma. 2010;51(6):975-982.

24. Rubinstein P, Adamson JW, Stevens C. The Placental/Umbilical Cord Blood Program of the New York Blood Center. A progress report. Ann N Y Acad Sci. 1999;872:328-334.

25. Gluckman E, Rocha V. History of the clinical use of umbilical cord blood hematopoietic cells. Cytotherapy. 2005;7(3):219-227. 
26. Bone Marrow Donors Worldwide. Number of donors/CBU's per registry in BMDW; 2014. Available from: https://www.bmdw.org/numberofdonors/login.php. Accessed March 13, 2014.

27. Meijer I, Knight M, Mattson P, Mostert B, Simmonds P, Vullings W. Cord blood banking in the UK: an international comparison of policy and practice; 2009. Available from: http://www.technopolis-group. com/resources/downloads/reports/952_final_090114.pdf. Accessed March 13, 2014

28. Navarrete C, Contreras M. Cord blood banking: a historical perspective. Br J Haematol. 2009;147(2):236-245.

29. Atkin K, Ahmad WI, Anionwu EN. Screening and counselling for sickle cell disorders and thalassaemia: the experience of parents and health professionals. Soc Sci Med. 1998;47(11):1639-1651.

30. Sullivan MJ. Banking on cord blood stem cells. Nat Rev Cancer. 2008;8(7):555-563.

31. Rubinstein P. Why cord blood? Hum Immunol. 2006;67(6):398-404.

32. Foundation for the Accreditation of Cell Therapy. Fifth Edition NetCordFACT International Standards for Cord Blood Collection, Banking, and Release for Administration; 2013. Available at: http://www.factweb. org/forms/store/ProductFormPublic/search?action=1\&Product_ productNumber=627. Accessed March 13, 2014.

33. Sun J, Allison J, McLaughlin C, et al. Differences in quality between privately and publicly banked umbilical cord blood units: a pilot study of autologous cord blood infusion in children with acquired neurologic disorders. Transfusion. 2010;50(9):1980-1987.

34. Bart T. Cost effectiveness of cord blood versus bone marrow and peripheral blood stem cells. Clinicoecon Outcomes Res. 2012;2: 141-147.

35. Ballen K. Challenges in umbilical cord blood stem cell banking for stem cell reviews and reports. Stem Cell Rev. 2010;6(1):8-14.

36. Petrini C. Ethical issues in umbilical cord blood banking: a comparative analysis of documents from national and international institutions. Transfusion. 2013;53(4):902-910.

37. Ferreira E, Pasternak J, Bacal N, de Campos Guerra JC, Mitie Watanabe F. Autologous cord blood transplantation. Bone Marrow Transplant. 1999;24(9):1041.

38. Hayani A, Lampeter E, Viswanatha D, Morgan D, Salvi SN. First report of autologous cord blood transplantation in the treatment of a child with leukemia. Pediatrics. 2007;119(1):e296-e300.

39. Fruchtman SM, Hurlet A, Dracker R, et al. The successful treatment of severe aplastic anemia with autologous cord blood transplantation. Biol Blood Marrow Transplant. 2004;10(11):741-742.

40. Ballen KK, Barker JN, Stewart SK, Greene MF, Lane TA; American Society of Blood and Marrow Transplantation. Collection and preservation of cord blood for personal use. Biol Blood Marrow Transplant. 2008;14(3):356-363.

41. Nietfeld JJ, Pasquini MC, Logan BR, Verter F, Horowitz MM. Lifetime probabilities of hematopoietic stem cell transplantation in the US. Biol Blood Marrow Transplant. 2008;14(3):316-322.

42. Nietfeld JJ, Pasquini MC, Logan BR, Verter F, Horowitz MM. On the probability of using cord blood. Biol Blood Marrow Transplant. 2008;14(6):724-725.

43. Kline RM. Whose blood is it, anyway? Sci Am. 2001;284(4): 42-49.

44. Pasquini MC, Logan BR, Verter F, Horowitz MM, Nietfeld JJ. The likelihood of hematopoietic stem cell transplantation (HCT) in the United States: implications for umbilical cord blood storage. Blood. 2005;106(11):1330.

45. Rosenthal J, Woolfrey AE, Pawlowska A, Thomas SH, Appelbaum F, Forman S. Hematopoietic cell transplantation with autologous cord blood in patients with severe aplastic anemia: an opportunity to revisit the controversy regarding cord blood banking for private use. Pediatr Blood Cancer. 2011;56(7):1009-1012.

46. Contu L. Il dibattito sul sangue del cordone ombelicale: a chi e a che cosa serve la conservazione privata del sangue cordonale? 2011. Available from: http://www.adoces.it/materiale/rapporto2011.pdf. Accessed March 13, 2014. Italian.
47. Brand A, Rebulla P, Engelfriet CP, et al. Cord blood banking. Vox Sang. 2008;95(4):335-348.

48. Smith FO. Why do parents engage in private cord blood banking: Fear, realistic hope or a sense of control? Pediatr Blood Cancer. 2011;56(7):1003-1004.

49. Webb S. Banking on cord blood stem cells. Nat Biotechnol. 2013;31(7): 585-588.

50. Comité Italo-Français pour le bon usage du sang du cordon ombilical. Audition au Parlement Européen sur le don de la solidarité, collection privée et la préservation du sang de cordon ombilical; 2011. Available from: http://www.adoces.it/wordpress/wp-content/uploads/2011/03/ Eurodeputati-francese.pdf. Accessed March 13, 2014. French.

51. NetCord. Position statement on cord blood for autologous use. NetCord Newsletter. January 2, 2008.

52. Butler MG, Menitove JE. Umbilical cord blood banking: an update. J Assist Reprod Genet. 2011;28(8):669-676.

53. Ministero del Lavoro, della Salute e delle Politiche Sociali. Decreto 18 novembre 2009. Disposizioni in materia di conservazione di cellule staminali da sangue del cordone ombelicale per uso autologo dedicato. Gazzetta Ufficiale Repubblica Italiana. 2009;303:19-24. Italian.

54. Petrini C. European regulations on cord blood banking: an overview. Transfusion. 2012;52(3):668-679.

55. Wall DA. Issues in the quality of umbilical cord blood stem cells for transplantation: challenges in cord blood banking quality management. Transfusion. 2005;45(6):826-828.

56. Gluckman E, Ruggeri A, Volt F, Cunha R, Boudjedir K, Rocha V. Milestones in umbilical cord blood transplantation. Br J Haematol. 2011;154(4):441-447.

57. Smythe J, Armitage S, McDonald D, et al. Directed sibling cord blood banking for transplantation: the 10-year experience in the national blood service in England. Stem Cells. 2007;25(8):2087-2093.

58. Harris DT. Non-haematological uses of cord blood stem cells. $\mathrm{Br} J$ Haematol. 2009;147(2):177-184.

59. Jensen A, Hamelmann E. First autologous cell therapy of cerebral palsy caused by hypoxic-ischemic brain damage in a child after cardiac arrest-individual treatment with cord blood. Case Rep Transplant. 2013;2013:951827.

60. Min K, Song J, Kang JY, et al. Umbilical cord blood therapy potentiated with erythropoietin for children with cerebral palsy: a double-blind, randomized, placebo-controlled trial. Stem Cells. 2013;31(3):581-591.

61. Fisk NM, Atun R. Public-private partnership in cord blood banking. BMJ. 2008;336(7645):642-644.

62. Umbilical cord blood banking Richard Branson's way. Lancet. 2007;369(9560):437.

63. Ministerio de Sanidad y Consumo. Real decreto 1301/2006, de 10 de noviembre, par el que se stablecen las normas de calidad y seguridad para la donación, la obtención, la evaluación, el procesamiento, la preservación, el almacenamiento y la distribución de células y tejidos y se aprubean las normas de coordinación y funcionamiento para su uso en humanos. Bol Oficíal Estado. 2006;270:39475-39498. Spanish.

64. Aznar Lucea J. Umbilical cord blood banks. Ethical aspects. Public versus private banks. Cuad Bioet. 2012;23(78):269-285.

65. World Marrow Donor Association. Combined Private and Public Banking of Cord Blood and Other Related Products; 2012. Available from: http:/www.worldmarrow.org/fileadmin/Committees/ CBWG/20120328-CBWG-PPR-Hybrid.pdf. Accessed March 13, 2014.

66. Pontifical Academy for Life. Banks of Umbilical Cord Blood. Rome: Pontifical Academy for Life; 2013:55.

67. Health Resources and Services Administration. The need for more cord blood donations. Available from: http://bloodcell.transplant.hrsa.gov/ CORD/The_Need/index.html. Accessed March 13, 2014.

68. Howard DH, Maiers M, Kollman C, Logan B, Gragert L, Setterholm M. A cost-benefit analysis of increasing cord blood inventory levels: An analysis prepared for the Committee on Establishing a National Cord Blood Stem Cell Bank. Washington, DC: Institute of Medicine; 2005:221-241. 
69. Querol S, Mufti GJ, Marsh SG, et al. Cord blood stem cells for hematopoietic stem cell transplantation in the UK: how big should the bank be? Haematologica. 2009;94(4):536-541.

70. Querol S, Rubinstein P, Marsh SG, Goldman J, Madrigal JA. Cord blood banking: 'providing cord blood banking for a nation'. Br J Haematol. 2009;147(2):227-235.

71. Bordet S, Nguyen TM, Knoppers BM, Isasi R. Use of umbilical cord blood for stem cell research. J Obstet Gynaecol Can. 2010;32(1): 58-61.

72. Parazzi V, Lazzari L, Rebulla P. Platelet gel from cord blood: a novel tool for tissue engineering. Platelets. 2010;21(7):549-554.

73. Faden RR, Dawson L, Bateman-House AS, et al. Public stem cell banks: considerations of justice in stem cell research and therapy. Hastings Cent Rep. 2003;33(6):13-27.

74. Greppi N, Mazzucco L, Galetti G, et al. Treatment of recalcitrant ulcers with allogeneic platelet gel from pooled platelets in aged hypomobile patients. Biologicals. 2011;39(2):73-80.

75. Sirchia G, Rebulla P, Tibaldi S, Lecchi L. Cost of umbilical cord blood units released for transplantation. Transfusion. 1999;39(6):645-650.

76. Organización Nacional de Trasplantes. Plan Nacional de Sangre de Cordón Umbilical; 2008. Available from: http://www.ont.es/infesp/ Paginas/PlanNacionalSCU.aspx. Accessed March 13, 2014. Spanish.

77. Kollman C, Abella E, Baitty RL, et al. Assessment of optimal size and composition of the US National Registry of hematopoietic stem cell donors. Transplantation. 2004;78(1):89-95.

78. Hollands P, McCauley C. Private cord blood banking: current use and clinical future. Stem Cell Rev. 2009;5(3):195-203.

79. HR 2520 (109th): Stem Cell Therapeutic and Research Act of 2005; December 19, 2005. Available at: http://www.govtrack.us/congress/ bills/109/hr2520/text. Accessed March 13, 2014.

80. Kaimal AJ, Smith CC, Laros RK Jr, Caughey AB, Cheng YW. Cost-effectiveness of private umbilical cord blood banking. Obstet Gynecol. 2009;114(4):848-855.

81. Waldby C, Mitchell, R. Tissue Economies: Blood, Organ and Cell Lines in Late Capitalism. London: Duke University Press; 2006.
82. Esposito R. Interview. Diacritics. 2006;36:49-56.

83. Esposito R. Bios: Biopolitics and Philosophy. Minneapolis, MN: University of Minnesota Press; 2008.

84. Brown N, Machin L, McLeod D. Immunitary bioeconomy: the economisation of life in the international cord blood market. Soc Sci Med. 2011;72(7):1115-1122.

85. Benjamin R. A lab of their own: genomic sovereignty as postcolonial science policy. Policy Soc. 2009;28:341-355.

86. Foeken LM, Green A, Hurley CK, Marry E, Wiegand T, Oudshoorn M; Donor Registries Working Group of the World Marrow Donor Association (WMDA). Monitoring the international use of unrelated donors for transplantation: the WMDA annual reports. Bone Marrow Transplant. 2010;45(5):811-818.

87. Pamphilon D. Quality approaches in cell therapy: patient and therapy related aspects. International Society of Blood Transfusion. ISBT Science Series. 2009;4:24-30.

88. World Health Organization. WHO guiding principles on human cell, tissue and organ transplantation; 2010. Available at: http://www. who.int/entity/transplantation/Guiding_PrinciplesTransplantation_ WHA63.22en.pdf. Accessed March 13, 2014.

89. Council of Europe. Convention for the Protection of Human Rights and Dignity of the Human Being with Regard to the Application of Biology and Medicine: Convention on Human Rights and Biomedicine. Oviedo, April 4, 1997. Available from: http://conventions.coe.int/Treaty/en/ Treaties/html/164.htm. Accessed on February 2, 2014.

90. European Parliament, Council of the European Union, European Commission. Charter for the Fundamental Rights of the European Union (2000/C 364/01). Official J Eur Comm. 2000;C364:1-22.

91. Lenk C, Beier K. Is the commercialisation of human tissue and body material forbidden in the countries of the European Union? J Med Ethics. 2012;38(6):342-346.

92. Burningham S, Ollenberger A, Caulfield T. Commercialization and stem cell research: a review of emerging issues. Stem Cells Dev. 2013 22 Suppl 1:80-84

\section{Publish your work in this journal}

The Journal of Blood Medicine is an international, peer-reviewed, open access, online journal publishing laboratory, experimental and clinical aspects of all topics pertaining to blood based medicine including but not limited to: Transfusion Medicine; Blood collection, Donor issues, Transmittable diseases, and Blood banking logistics; Immunohematology; Artificial and alternative

\section{Dovepress}

blood based therapeutics; Hematology; Biotechnology/nanotechnology of blood related medicine; Legal aspects of blood medicine; Historical perspectives. The manuscript management system is completely online and includes a very quick and fair peer-review system. Visit http://www.dovepress.com/ testimonials.php to read real quotes from published authors. 